\title{
Diploflavone, a New Flavonoid from Diplotropis ferruginea Benth. (Fabaceae)
}

\section{Jackson Roberto G. S. Almeida ${ }^{a, b}$, José Maria Barbosa-Filho ${ }^{*, a}$, Analúcia G. S. Cabral ${ }^{a}$, Maria de Fátima Agra ${ }^{a}$, Emidio V. Leitão da-Cunha ${ }^{a, c}$, Marcelo S. da Silva ${ }^{a}$, Silene C. do Nascimento ${ }^{d}$ and Raimundo Braz-Filho ${ }^{e}$}

${ }^{a}$ Laboratório de Tecnologia Farmacêutica, Universidade Federal da Paraíba, CP 5009, 58051-970 João Pessoa - PB, Brazil

${ }^{b}$ Universidade Federal do Vale do São Francisco, CP 252, 56306-410 Petrolina - PE, Brazil

${ }^{c}$ Departamento de Farmácia, CCBS, Universidade Estadual da Paraíba, 58100-000 Campina Grande - PB, Brazil

${ }^{d}$ Departamento de Antibióticos, Universidade Federal de Pernambuco, 50740-521 Recife - PE, Brazil

${ }^{e}$ Setor de Química de Produtos Naturais- LCQUI-CCT - Universidade Estadual do Norte Fluminense, 28015-620 Campos, Rio de Janeiro - RJ, Brazil

\begin{abstract}
A análise química de Diplotropis ferruginea Benth. resultou no isolamento da 3-metoxiflavona, 3-metoxi-6-O-prenil-6",6"-dimetilcromeno-(7,8,2",3")-flavona, à qual foi dado o nome trivial de diploflavona (1), bem como da 3,6-dimetoxi-6",6"-dimetilcromeno-(7,8,2",3")-flavona (2). A estrutura do novo composto foi estabelecida por análises espectrais. A atividade citotóxica dos compostos isolados foi testada contra células NCI-H292 (carcinoma de pulmão), HEp-2 (carcinoma de laringe) e KB (carcinoma epidermóide oral). As células HEp-2 foram as mais afetadas pelas substâncias testadas.
\end{abstract}

The chemical examination of Diplotropis ferruginea Benth. resulted in the isolation of a new 3-methoxyflavone, 3-methoxy-6-O-prenyl-6",6"-dimethylchromene-(7,8,2",3")-flavone, to which was given the trivial name diploflavone (1); as well as the known 3,6-dimethoxy-6",6"dimethylchromene-(7,8,2",3")-flavone (2). The structure of the new compound was established by spectral analyses. Cytotoxic activity of the isolated compounds was tested against the cells NCIH292 (lung carcinoma), HEp-2 (larynx carcinoma) and KB (oral epidermoid carcinoma). The cells HEp-2 were the most affected by the substances tested.

Keywords: Diplotropis ferruginea, Fabaceae, flavonoids, cytotoxicity

\section{Introduction}

The Fabaceae have a cosmopolitan distribution, consisting of $c a 700$ genera and more than 17000 species. ${ }^{1}$ The genus, Diplotropis consists of approximately 22 species, including, Diplotropis ferruginea Benth. Investigations of only two species have been reported in the literature: the isolation of quinolizidine alkaloids from Diplotropis martiusii, ${ }^{2}$ and flavonoids from Diplotropis purpurea. $^{3}$

Diplotropis ferruginea is a tree native to Northeastern Brazil, where it is popularly known as "sucupira". It is used in folk medicine for the treatment of rheumatism, arthritis and diabetes. ${ }^{4}$ Recently, a chemical investigation

* e-mail: jbarbosa@ltf.ufpb.br of this species resulted in the isolation of lupeol, ethyl 2-hydroxy-4-methoxy-6-propyl benzoate ${ }^{5}$ and of the flavonoid 3,4,5,8-tetramethoxy-6,7,2",3"-furanoflavan. ${ }^{6}$ Spasmolytic activity was reported for the crude EtOH extract of this plant. ${ }^{\text {? }}$

This paper describes the isolation of two more flavonoids, whose structures were established by spectroscopic techniques, mainly EIMS and 1D and 2D NMR.

\section{Experimental}

General experimental procedures

Melting points were determined on a REICHERT, model R3279 "Kofler" apparatus, and are uncorrected. IR spectra were obtained in $\mathrm{KBr}$ on a BOMEM model MB 100 
spectrophotometer. ${ }^{1} \mathrm{H}$ and ${ }^{13} \mathrm{C}$ NMR spectra were run on a Jeol Eclipse+ 400 spectrometer operating at $400 \mathrm{MHz}$ for ${ }^{1} \mathrm{H}$ and $100 \mathrm{MHz}$ for ${ }^{13} \mathrm{C}$, using $\mathrm{CDCl}_{3}$ as solvent (approximately $10 \mathrm{mg}$ of sample were dissolved in $0.5 \mathrm{~mL}$ of solvent and transferred into a $5 \mathrm{~mm}$ NMR tube) and solvent signals were used as internal reference for the chemical shifts $\delta_{\mathrm{H}} 7.26\left(\mathrm{CHCl}_{3}\right)$ and $\delta_{\mathrm{C}} 77.00\left(\mathrm{CDCl}_{3}\right)$. The one-dimensional (1D) ${ }^{1} \mathrm{H}$ and ${ }^{13} \mathrm{C}$ NMR spectra were acquired under standard conditions ( $5 \mathrm{~mm}$ multinuclear probe). The two-dimensional (2D) experiments were acquired and processed with the Delta software provided by Jeol. Standard pulse sequences were used for all experiments. ${ }^{1} \mathrm{H}-{ }^{1} \mathrm{H}-\mathrm{COSY}$ spectra were obtained with X-points 512/Y-points 256, X-resolution 11.7 Hz/Yresolution $23.4 \mathrm{~Hz}$, X-acquisition time $85.4 \mathrm{~ms} / \mathrm{Y}$-acquisition time $42.7 \mathrm{~ms}$, pulse $90^{\circ}$, relaxation delay $1.5 \mathrm{~s}$, zerofill: 4 . For homonuclear $2 \mathrm{D}^{1} \mathrm{H}-{ }^{1} \mathrm{H}-\mathrm{NOESY}$ experiments were used mixing time $0.5 \mathrm{~s}, \mathrm{X}$-points 512/Y-points 256, X-resolution 11. 7Hz/Y-resolution $23.4 \mathrm{~Hz}, \mathrm{X}$-acquisition time $85.4 \mathrm{~ms} /$ Y-acquisition time $42.7 \mathrm{~ms}$, pulse $90^{\circ}$ relaxation delay $1.5 \mathrm{~s}$, zerofill: 4. Two-dimensional inverse hydrogen detected heteronuclear shift correlation ${ }^{1} \mathrm{H}-{ }^{13} \mathrm{C}-\mathrm{HMQC}-{ }^{1} J_{\mathrm{CH}}$ spectra were obtained with ${ }^{1} J_{\mathrm{CH}}=140 \mathrm{~Hz}, \mathrm{X}$-points $1024 / \mathrm{Y}$-points 128, X-resolution $5.86 \mathrm{~Hz} / Y$-resolution $196 \mathrm{~Hz}$, X-pulse $90 \%$ Y-pulse $90^{\circ}, \mathrm{X}$-acquisition time $0.17 \mathrm{~s} / \mathrm{Y}$-acquisition time $5.09 \mathrm{~ms}$, pulse $90^{\circ}$, relaxation delay $2.0 \mathrm{~s}$, gradient $1 / 31 \mathrm{~ms}$ square, zerofill: 4. Two-dimensional inverse hydrogen detected heteronuclear long-range correlation ${ }^{1} \mathrm{H}-{ }^{13} \mathrm{C}$ HMBC- ${ }^{\mathrm{n}} J_{\mathrm{CH}}(\mathrm{n}=2$ and 3 ) experiments were carried out by using ${ }^{\mathrm{n}} J_{\mathrm{CH}}=\mathrm{J}$ constant $140 \mathrm{~Hz} / \mathrm{J}$ long range $8 \mathrm{~Hz}, \mathrm{X}$-points 1024/Y-points 128, X-resolution 5.86 Hz/Y-resolution 196 $\mathrm{Hz}, \mathrm{X}$-pulse $90^{\circ} / \mathrm{Y}$-pulse $90^{\circ}, \mathrm{X}$-acquisition time $0.17 \mathrm{~s} / \mathrm{Y}-$ acquisition time $5.09 \mathrm{~ms}$, pulse $90^{\circ}$, relaxation delay $2.0 \mathrm{~s}$, gradient $1 / 31 \mathrm{~ms}$ square, zerofill: 4 . EIMS were measured at $70 \mathrm{eV}$ on a GC/MS System Shimadzu QP-5050.

\section{Plant material}

The stem bark of Diplotropis ferruginea was collected in the municipality of Caraúbas, State of Rio Grande do Norte, Northeastern Brazil in May 2002. Botanic material was identified by Prof. Maria de Fátima Agra, of the Laboratório de Tecnologia Farmacêutica. A voucher specimen (AGRA \& D. ALMEIDA 5559) is deposited at the Herbario Prof. Lauro Pires Xavier (JPB), of the Universidade Federal da Paraíba.

\section{Extraction and isolation}

The dried and powdered stem bark of D. ferruginea ( $3 \mathrm{~kg}$ ) was exhaustively extracted with $95 \% \mathrm{EtOH}$ at room temperature. The extract was concentrated under vacuum yielding $95 \mathrm{~g}$ of the crude product. This was suspended in a $\mathrm{MeOH}: \mathrm{H}_{2} \mathrm{O}(3: 7 \mathrm{v} / \mathrm{v})$ mixture and partitioned with hexane, $\mathrm{CHCl}_{3}$ and EtOAc. The hexane fraction was then subjected to silica gel column chromatography and eluted with hexane, $\mathrm{CHCl}_{3}$ and $\mathrm{MeOH}$ in an increasing polarity gradient to give 152 fractions. The fractions were monitored by TLC and classified into 25 groups. Fraction 97-102 was purified by preparative TLC over silica gel using $\mathrm{CHCl}_{3}: \mathrm{MeOH}(9: 1)$ to afford flavonoid 1 (61 mg) and the fraction 89-96 was purified in the same way using hexane:EtOAc (2:1) to afford flavonoid 2 (123 mg).

\section{Biological assay}

The cytotoxic activity assays were based on the methylazoetetrazolium (MTT) method or the 3-(4,5dimethylazol-2-yl)-3,5-diphenyltetrazolium bromide method. ${ }^{8}$ For the evaluation of cytotoxity the cellular strain HEp2 (larynx carcinoma) NCIH-292 (lung carcinoma) KB (mouth carcinoma) ${ }^{9}$ with proven viability were used. The cells were grown in MEM- Minimal Essential Medium ${ }^{10}$ with $10 \%$ bovine fetal serum containing $1 \%$ antibiotics solution (penicillin $1000 \mathrm{UI} \mathrm{mL}^{-1}+$ streptomycin $250 \mathrm{mg}$ $\left.\mathrm{mL}^{-1}\right)$ and $1 \%$ glutamine $(200 \mu \mathrm{M})$. A cellular suspension of $5 \times 10^{4}$ cells $\mathrm{mL}^{-1}$ was used and distributed in plates of 96 wells. The test samples of $0.15 \mathrm{~mL}$ were added into each well. The plates were incubated for $72 \mathrm{~h}$ at $37^{\circ} \mathrm{C}$ in a humid atmosphere enriched with $5 \% \mathrm{CO}_{2}$. After incubation $15 \mathrm{~mL}$ MTT in phosphate buffered saline (BPS) solution at $\left(5 \mathrm{mg} \mathrm{mL}^{-1}\right)$ was added into each well. After $2 \mathrm{~h}$ the culture medium was removed and $100 \mu \mathrm{L}$ of DMSO were added in each well for quantitation of blue formazan. The readings were performed with the aid of a Multskan ELX 800 cell reader (Bio-Tec Instruments - USA) at $540 \mathrm{~nm}$.

\section{3-Methoxy-6-O-prenyl-6”,6"-dimethylchromene-} (7,8,2”,3")-flavone or diploflavone, (1)

It was obtained as amorphous powder, mp 163-165 ${ }^{\circ} \mathrm{C}$. IR $(\mathrm{KBr}) v_{\max } / \mathrm{cm}^{-1}: 3062,2971,2847,1620,1404,1379$,

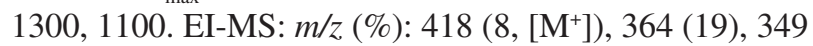
(100, [ $\mathrm{M}^{+}$- prenyl]), 335 (38) (Calc. for $\mathrm{C}_{26} \mathrm{H}_{26} \mathrm{O}_{5}$ ). ${ }^{1} \mathrm{H} \mathrm{NMR}$ $\left(\mathrm{CDCl}_{3}, 400 \mathrm{MHz}\right)$ and ${ }^{13} \mathrm{C} \mathrm{NMR}\left(\mathrm{CDCl}_{3}, 100 \mathrm{MHz}\right)$ (Table 1).

3,6-Dimethoxy-6",6"-dimethylchromene-(7,8,2",3")flavone, (2)

It was obtained as amorphous powder, mp 203-204 ${ }^{\circ} \mathrm{C}$. IR (KBr) $v_{\text {max }} / \mathrm{cm}^{-1}: 2995,2844,1615,1402,1382,1300$, 1100. EI-MS: $\mathrm{m} / \mathrm{z}(\%): 364\left(63,\left[\mathrm{M}^{+}\right]\right), 349(100$, 
$\left.\left[\mathrm{M}^{+}-\mathrm{CH}_{3}\right]\right), 319$ (4) (Calc. for $\left.\mathrm{C}_{22} \mathrm{H}_{20} \mathrm{O}_{5}\right)$. ${ }^{1} \mathrm{H} \mathrm{NMR}\left(\mathrm{CDCl}_{3}\right.$, $400 \mathrm{MHz})$ and ${ }^{13} \mathrm{C} \mathrm{NMR}\left(\mathrm{CDCl}_{3}, 100 \mathrm{MHz}\right)$.

\section{Results and Discussion}

Flavonoid 1 was obtained as a colorless amorphous solid. Its molecular formula was deduced as $\mathrm{C}_{26} \mathrm{H}_{26} \mathrm{O}_{5}$ (14 degrees of unsaturation), supported by the occurrence of the molecular ion at $m / z 418$ in the MS, in combination with ${ }^{1} \mathrm{H}$ and ${ }^{13} \mathrm{C}$-APT-NMR spectral data. The IR spectrum showed absorptions at $1620 \mathrm{~cm}^{-1}$, attributed to an $\alpha-\beta$ unsaturated carbonyl group; $3062 \mathrm{~cm}^{-1}$ attributed to unsaturated C-H and absorptions in the region 1379-1404 $\mathrm{cm}^{-1}$, suggesting the presence of a gem-dimethyl group. ${ }^{1} \mathrm{H}$ NMR of 1 showed signals at $\delta_{\mathrm{H}} 8.07(2 \mathrm{H}, \mathrm{br}, \mathrm{d} J=7.7 \mathrm{~Hz})$ and $7.56-7.46(3 \mathrm{H}$, $\mathrm{m})$ which indicates the possibility of a mono-substituted ring $\mathrm{B}$ in a flavonoid. The presence of a 2,2-dimethylchromene moiety was indicated by the characteristic signals of its two vinyl hydrogens forming an $\mathrm{AB}$ system ${ }^{11}$ at $\delta_{\mathrm{H}}$ $5.74(1 \mathrm{H}, \mathrm{d}, J=9.9 \mathrm{~Hz})$ and $6.87(1 \mathrm{H}, \mathrm{d}, J=9.9 \mathrm{~Hz})$ and a signal at $\delta_{\mathrm{H}} 1.54(6 \mathrm{H}, \mathrm{s})$ attributed to the two methyl groups. A signal at $\delta_{\mathrm{H}} 1.79(6 \mathrm{H}, \mathrm{s})$ was also observed and signals at $\delta_{\mathrm{H}} 4.68(1 \mathrm{H}, \mathrm{d}, J=6.2 \mathrm{~Hz})$ and $5.53(1 \mathrm{H}, \mathrm{t}, J=6.2 \mathrm{~Hz})$, suggesting the presence of a prenyl group in the molecule. This suggestion is confirmed by the ${ }^{13} \mathrm{C}$-APT NMR spectra which shows signals at $\delta_{\mathrm{C}} 18.25$ and 25.72, for 2 methyl carbons and a methylene carbon at $\delta_{C} 66.29$. The chemical shift of the methylene carbon in the ${ }^{13} \mathrm{C}$ NMR indicates that the prenyl group is bound to an oxygen atom. The HMBC experiment showed the location of the $O$-prenyl group at C-6, due to the ${ }^{3} J_{\mathrm{CH}}$ correlation between the signal at $\delta_{\mathrm{H}}$ 4.68 (prenyl's methylene hydrogens) with the signal at $\delta_{\mathrm{C}}$ 146.06 (C-6). The analysis of all the spectral data for $\mathbf{1}$ led to the elucidation of its structure as 3-methoxy-6-O-prenyl6",6"-dimethylchromene-(7,8,2",3")-flavone. This substance is described here for the first time and was given the trivial name diploflavone.

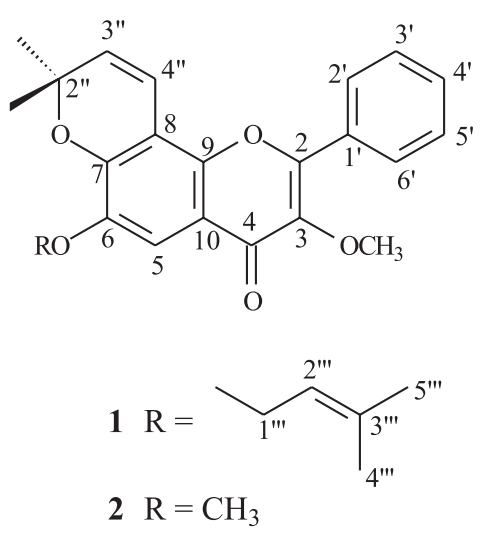

Figure 1. Flavonoids from Diplotropis ferruginea.
Flavonoid 2 was isolated as a colorless amorphous solid. Its molecular formula deduced as $\mathrm{C}_{22} \mathrm{H}_{20} \mathrm{O}_{5}(13$ degrees of unsaturation), was confirmed by the molecular ion at $\mathrm{m} / \mathrm{z} 364$ in the MS in combination with ${ }^{1} \mathrm{H}-\mathrm{NMR}$ (1D and $2 \mathrm{D}^{1} \mathrm{H}-{ }^{1} \mathrm{H}-\mathrm{COSY}$ ) and ${ }^{13} \mathrm{C}-\mathrm{APT}-\mathrm{NMR}$ spectral data. IR and ${ }^{1} \mathrm{H}$ and ${ }^{13} \mathrm{C}$-NMR spectra showed the similarity with substance 1 . The only difference between the two substances was the absence of the prenyl moiety in $\mathbf{2}$, having a methoxy in the same position. The presence of the methoxy group was indicated by the signal at $\delta_{\mathrm{H}} 3.97$ $(3 \mathrm{H}, \mathrm{s})$. The substance was thus characterized as the flavonoid 3,6-dimethoxy-6",6"-dimethylchromene(7,8,2",3")-flavone (2), previously isolated from Bowdichia virgilioides and the NMR data are in accordance with the literature. ${ }^{12}$

The 2D experiments HMQC and HMBC were used to confirm the ${ }^{1} \mathrm{H}$ and ${ }^{13} \mathrm{C}$ chemical shifts of $\mathbf{1}$ (Table 1) and 2. ${ }^{12}$

Table 1. ${ }^{1} \mathrm{H}(400 \mathrm{MHz})$ and ${ }^{13} \mathrm{C}(100 \mathrm{MHz})$ NMR data for $\mathbf{1}$ including results obtained by heteronuclear 2D shift-correlated HMQC and $\mathrm{HMBC}$ spectra, in $\mathrm{CDCl}_{3}$ as solvent and TMS as internal reference. Chemical shifts in $\delta(\mathrm{ppm})$ and coupling constants $(J$, in parenthesis) in $\mathrm{Hz}^{*}$

\begin{tabular}{|c|c|c|c|c|}
\hline \multirow{2}{*}{ Carbon } & \multicolumn{2}{|c|}{${ }^{1} \mathrm{H}-{ }^{13} \mathrm{C}-\mathrm{COSY}-{ }^{-1} J_{\mathrm{CH}}$} & \multicolumn{2}{|c|}{${ }^{1} \mathrm{H}-{ }^{13} \mathrm{C}-\mathrm{COSY}{ }^{\mathrm{n}} J_{\mathrm{CH}}$} \\
\hline & $\delta_{\mathrm{C}}$ & $\delta_{\mathrm{H}}$ & ${ }^{2} J_{\mathrm{CH}}$ & ${ }^{3} J_{\mathrm{CH}} \mathrm{e}^{4} J_{\mathrm{CH}}$ \\
\hline \multicolumn{5}{|l|}{ C } \\
\hline 2 & 154.31 & - & & H-2'/H-6' \\
\hline 3 & 140.96 & - & & $\mathrm{MeO}-3$ \\
\hline 4 & 174.21 & - & & H-5 \\
\hline 6 & 146.06 & - & & $2 \mathrm{H}-1^{\prime} "$ \\
\hline 7 & 147.93 & - & & H-5; H-4" \\
\hline 8 & 110.16 & - & $\mathrm{H}-4 "$ & H-3” \\
\hline 9 & 146.15 & - & & H-5; H-4" \\
\hline 10 & 117.19 & - & $\mathrm{H}-5$ & \\
\hline 1 ' & 131.29 & - & H-2'/H-6' & H-3'/H-5' \\
\hline $2 "$ & 77.91 & - & $3 \mathrm{H}-5 " / 3 \mathrm{H}-6 "$ & H-4” \\
\hline 3," & 137.78 & - & $3 \mathrm{H}-4^{\prime}, " / 3 \mathrm{H}-5, "$, & $2 \mathrm{H}-1^{\prime \prime}$ \\
\hline \multicolumn{5}{|l|}{ CH } \\
\hline 5 & 106.5 & $7.52(\mathrm{~s})$ & & \\
\hline $2^{\prime}, 6^{\prime}$ & 128.1 & 8.07 (br, d, 7.7) & & \\
\hline $3^{\prime}, 5^{\prime}$ & 128.44 & 7.56-7.46 (m) & & \\
\hline $4^{\prime}$ & 131.24 & 7.56-7.46 (m) & & H-2'/H-6' \\
\hline $4 "$ & 115.32 & $6.87(\mathrm{~d}, 9.9)$ & & \\
\hline $3 "$ & 131.27 & $5.74(\mathrm{~d}, 9.9)$ & & $3 \mathrm{H}-5 " / 3 \mathrm{H}-6 "$ \\
\hline 2 '” & 119.48 & $5.53(\mathrm{t}, 6.2)$ & $2 \mathrm{H}-1{ }^{\prime}$, & $3 \mathrm{H}-4^{\prime}, " / 3 \mathrm{H}-5^{\prime}$, \\
\hline $\begin{array}{l}\mathbf{C H}_{2} \\
1,,{ }^{2}\end{array}$ & 66.29 & $4.68(\mathrm{~d}, 6.2)$ & & \\
\hline $\begin{array}{l}\mathrm{CH}_{3} \\
\mathrm{MeO}-3\end{array}$ & 60.02 & $3.89(\mathrm{~s})$ & & \\
\hline MeO-6 & - & - & - & - \\
\hline $5 ", 6 "$ & 27.83 & $1.54(\mathrm{~s})$ & & H-3” \\
\hline $4, "$ & 18.25 & $1.79(\mathrm{~s})$ & & $\mathrm{H}-2$ '”, \\
\hline $5^{\prime \prime \prime}$ & 25.72 & $1.79(\mathrm{~s})$ & & $\mathrm{H}-2^{\prime}$, \\
\hline
\end{tabular}

* Homonuclear ${ }^{1} \mathrm{H}-{ }^{1} \mathrm{H}-\mathrm{COSY}$ spectra were also used for these assignments. Chemical shifts of hydrogen atoms obtained from 1D ${ }^{1} \mathrm{H}$ NMR spectrum. Carbon atoms corresponding to $\mathrm{C}, \mathrm{CH}, \mathrm{CH}_{2}$ and $\mathrm{CH}_{3}$ deduced by comparative analysis of $\left\{{ }^{1} \mathrm{H}\right\}$ - and APT- ${ }^{13} \mathrm{C}$ spectra. 
Table 2. Cytotoxic activity of $\mathbf{1}$ and $\mathbf{2}$ against the cells KB, NCI-H 292 and HEp-2

\begin{tabular}{|c|c|c|c|c|c|c|}
\hline \multirow[b]{3}{*}{ Compound } & \multicolumn{6}{|c|}{ Cell strain } \\
\hline & \multicolumn{2}{|c|}{$\mathrm{KB}$} & \multicolumn{2}{|c|}{ NCI-H - 292} & \multicolumn{2}{|c|}{ HEp-2 } \\
\hline & $\begin{array}{l}\text { Concentration } \\
\left(\mu \mathrm{g} \mathrm{mL}^{-1}\right)\end{array}$ & $\%$ Inhibition & $\begin{array}{l}\text { Concentration } \\
\left(\mu \mathrm{g} \mathrm{mL}^{-1}\right)\end{array}$ & $\%$ Inhibition & $\begin{array}{l}\text { Concentration } \\
\left(\mu \mathrm{g} \mathrm{mL}^{-1}\right)\end{array}$ & $\%$ Inhibition \\
\hline \multirow[t]{4}{*}{1} & 10.0 & 26.2 & 10.0 & 29.1 & 10.0 & 41.0 \\
\hline & 5.0 & 21.2 & 5.0 & 26.7 & 5.0 & 24.8 \\
\hline & 2.5 & 19.0 & 2.5 & 9.8 & 2.5 & 3.4 \\
\hline & 1.25 & 18.0 & 1.25 & 11.0 & 1.25 & 3.4 \\
\hline \multirow[t]{4}{*}{2} & 10.5 & $18 \%$ & 10.0 & 10.0 & 10.0 & 21.0 \\
\hline & 5.0 & $16 \%$ & 5.0 & 9.2 & 5.0 & 17.9 \\
\hline & 2.5 & $15 \%$ & 2.5 & 3.8 & 2.5 & 13.8 \\
\hline & 1.25 & $15 \%$ & 1.25 & 3.8 & 1.25 & 8.8 \\
\hline
\end{tabular}

KB (oral epidermoid carcinoma), NCI-H - 292 (lung carcinoma), HEp-2 (larynx carcinoma).

The cytotoxic activity of cells NCI-H292 and KB were not affected by flavonoids $\mathbf{1}$ and $\mathbf{2}$, however, cells HEp-2 were affected by diploflavone (1). At the concentration of $10 \mu \mathrm{g} \mathrm{mL}^{-1}$ it showed an inhibition of proliferation of $41 \%$ (Table 2).

\section{Acknowledgements}

The authors are grateful to the Instituto do Milênio do Semi-Árido (IMSEAR/CNPq), CAPES and FAPERJ by financial support. Sincere thanks are also due to NAPRALERT.

\section{References}

1. Heywood, V. H.; Flowering Plants of the World, B. T. Batsford LTD: London, 1996, p.149.

2. Kinghorn, A. D.; Balandrin, M. F.; Lin, L. J.; Phytochemistry 1982, 21, 2269

3. Braz-Filho, R.; Gottlieb, O. R.; Pinho, S. L. V.; Monte, F. J. Q.; Rocha, A. I.; Phytochemistry 1973, 12, 1184.
4. Pio-Correia, M.; Dicionário das Plantas Úteis do Brasil e das Exóticas Cultivadas, Ministério da Agricultura: Brasil, 1984, p. 149.

5. Almeida, J. R. G. S.; Cunha, E. V. L.; Silva, M. S.; AthaydeFilho, P. F.; Braz-Filho, R.; Barbosa-Filho, J. M.; Rev. Bras. Farmacogn. 2003, 13, Suppl. 2, 44.

6. Almeida, J. R. G. S.; Cunha, E. V. L.; Silva, M. S.; Braz-Filho, R.; Marques, A. S.; Zheng, C.; Barbosa-Filho, J. M.; Ann. Magn. Reson. 2003, 1, 33.

7. Lima, J. T.; Claudino, F. S.; Cavalcante, F. A.; Almeida, J. R. G. S.; Barbosa-Filho, J. M.; Silva, B. A.; Rev. Bras. Ci. Farm. 2003, 39, Suppl. 2, 158.

8. Alley, M. C.; Scudiero, D. A.; Monks, A.; Hursey, M. L.; Czerwinski, M. J.; Fine, D. L.; Abbot, B. J.; Mayo, J. G.; Shoemaker, R. H.; Boyd, M. R.; Cancer Res. 1988, 48, 589.

9. Eagle, H.; Proc. Soc. Exper. Biol. Med. 1955, 89, 362.

10. Eagle, H.; Science 1959, 130, 432.

11. Campos, A. M.; Khac, D. D.; Fetizon, M.; Phytochemistry 1987, 26, 2819.

12. Arriaga, A. M. C.; Gomes, G. A.; Braz-Filho, R.; Fitoterapia 2000, 71, 211. 